\title{
Profile of Biology Teachers' Ability in Microbiology Practicum Trials Based on Local Materials During the Covid-19 Pandemic in Senior High School
}

\author{
Kusnadi*, Yanti Hamdiyati, Peristiwati, Any Fitriani, Purnamaulida Pratiwi, \\ Fitri Husni, Aditia Pratama
}

Department of Biology Education, FPMIPA, Indonesian University of Education

*Corresponding Author. Email: kusnadi@upi.edu

\begin{abstract}
This study aims to determine the profile of the ability of senior high school biology teachers in designing and testing local material-based bacteria and fungi cultivating practices during the Covid-19 pandemic. The method used in this study is a descriptive method with a qualitative approach. The participants in this study were 33 senior high school biology teachers at West Java province, Bandung. The data collection technique used the lesson plan assessment rubric, student worksheet, and practicum trial reports, besides that used both teacher profile and activities and obstacles questionnaires during the training. The research data analysis technique used data triangulation, data presentation, and conclusions. The data validity test includes data testing, data reliability testing, external validity/generalization. The results show that the profile of Senior High School biology teachers regarding teaching experience, as many as $63 \%$ of teachers had more than 10 years of teaching experience. The achievement of eligibility obtained a score of $85 \%$ (good category). These criteria include content, presentation, language, graphics, ease of usage, suitability of appearance, and usability of student worksheet features. The results of the questionnaire show that $91 \%$ of participants thought that the design and practical trial activities are very useful, $83 \%$ of participants thought that the material that had been delivered could be applied in schools. So that biology teachers can innovate further by using local materials to carry out practicum activities.
\end{abstract}

Article History

Received: 08-10-2021

Revised: 19-11-2021

Accepted: 23-11-2021

Published: 11-12-2021

Key Words:

Teachers' Ability, Practical Trials, Local Materials, Breeding of Bacteria and Fungi.

How to Cite: Kusnadi, K., Hamdiyati, Y., Peristiwati, P., Fitriani, A., Pratiwi, P., Husni, F., \& Pratama, A. (2021). Profile of Biology Teachers' Ability in Microbiology Practicum Trials Based on Local Materials During the Covid-19 Pandemic in Senior High School. Jurnal Kependidikan: Jurnal Hasil Penelitian dan Kajian Kepustakaan di Bidang Pendidikan, Pengajaran dan Pembelajaran, 7(4), 994-1002. doi:https://doi.org/10.33394/jk.v7i4.4383

https://doi.org/10.33394/jk.v7i4.4383

This is an open-access article under the CC-BY-SA License.

\section{Introduction}

The disease caused by the Coronavirus, also known as Covid-19, has been declared a global pandemic by the World Health Organization (WHO). The first case of Covid-19 in Indonesia was confirmed in early March 2020. The case quickly spread throughout the province so that the government established a national emergency response (Ferdyan, 2020). The establishment of a national emergency response makes the government activate rapid response mechanisms in various forms of prevention. One of the affected is the implementation of education in Indonesia. Teaching and learning activities that are always face-to-face are transformed into learning with an online system. Online learning is a learning system that is done with a platform that can help the teaching and learning process that is carried out even remotely. Online learning was carried out during the Covid-19 pandemic and consistent online learning found many obstacles both by students and teachers (Husna et al., 2021) So that the implementation of online learning is still not effective, especially in terms of learning materials. Biological learning that contains material that can be known by students cannot be obtained optimally (Ferdyan, 2020). Research conducted by Husna et al., 
(2021) shows that teachers have difficulty in carrying out online learning activities during pandemics.

Teachers play a fairly important role in the ongoing learning activities. Teachers according to Law No. 14 of 2005 are professional educators who have the task of educating, guiding, teaching, training, assessing, and evaluating learners on formal education. So that teachers have an important role in the process and learning activities in school. The importance of the role of the teacher in learning will never be replaced with any role. Teachers must be able to help with the difficulties faced by students in the learning process (Hasanah, 2012). Even technology that develops rapidly in aspects of life will not be able to replace the role of teachers. This is because the role of teachers is not just transferring science and technology. But as educators, the task of educators is that teachers must be able to educate learners into adults in the true sense (Suriansyah et al., 2015). In addition, the role of teachers according to Connel in Amanda (2018) is as an educator who encourages, supervises, and disciplines students, as role models, as teachers and mentors in the learning process, as teachers in their profession who always improve especially to update the material to be taught, as communicators to parents and the community, as managers of classroom administration management and as members of educational professional organizations.

Technological advances are changing the role of teachers from teachers who deliver the subject matter to facilitators who provide ease for learning. Teachers can provide diverse views from a variety of points of view when solving problems. The responsibility of teachers is evidenced by the willingness to continue to learn and adjust to the changing times, to prepare learners with future skills, and invite learners to learn to survive the life to come (Lestiyani, 2020). Teachers can provide media to review the material so that it can provide a varied experience. Through media and learning resources. Teachers can adjust learning methods. Learning methods provide the level of development of learners to connect new material with the material that has been mastered. Analyze the problem being studied. Teachers can understand the cognitive problems of students and simplify any existing problems. In addition, it can also make learning activities more meaningful and make students more enthusiastic (Amanda, 2018).

Meaningful learning activities can be obtained by carrying out practice activities. This activity can give a complete and meaningful impression for students because various senses such as hearing, touch, smell, and taste are involved in their activities (Supriatno, 2018). Practice activities are teaching and learning activities that involve students in observation, manipulation of objects and real materials (Millar, 2004). Practice activities in science are hands-on experiential learning activities that can lead students to think about the universe in which we live (Woodley, 2009; SCORE, 2009; Millar, 2002). Learning science in practice activities means not only studying content but also the process of providing a learning experience to build skills (how to know) to acquire knowledge (Supriatno, 2018; Rustaman, 2005). There are at least four reasons put forward by science education experts about the importance of laboratory trials. First, increase the motivation to learn science. Second, develop the basic skills to conduct experiments. Third, it becomes a vehicle for learning scientific approaches. Fourth, support in the understanding of the subject matter. The activities of the laboratory are one of the integral parts of learning activities, especially biological learning. Biological materials have many abstract concepts. Abstract concepts are defined as mental abstractions about an object or phenomenon that can be formed from various factual knowledge (Supriatno, 2018). One of the abstract concepts in biological learning is the cultivating of bacteria and fungi. The material was studied in class $\mathrm{X}$. Kemendikbud (2018) stated that in the biology learning of class X high school there is one of 
the Basic Competencies that will be studied, namely KD 3.5. Identify the structure, way of life, reproduction, and role of bacteria in life.

Based on limited interviews on high school teachers in the West Bandung Regency area, some of the obstacles faced by biology teachers in planning and implementing bacterial and fungal cultivating practices in schools include the unavailability of sterilization tools such as autoclaves and also the unavailability of chemicals such as beef extract and peptone. Another difficulty is related to teachers who have to use the tools of the laboratory. Most teachers who graduate from university are more accustomed to standard equipment that is different from school tools (Adisendjaja, 2008). In addition, procedural knowledge about the cultivating of bacteria and fungi in teachers is still limited. For that, it needs to alternate the design of practice bacteria and fungi using simple tools and ingredients found every day, such as panic presto autoclave substitute, beef broth extract instead of beef and peptone extract, and MSG as a source of amino acids and $\mathrm{NaCl}$. Alternative tools and materials based on local materials are relevant as a substitute for practice in the laboratory during the Covid- 19.

The importance of practice trial activities in biological learning is undeniable, this is because through practice trials student science process skills can be developed (Kusnadi et al., 2005). The student's science process is referred to through scientific work such as critical of a problem, developing hypotheses or questions, designing an experiment, answering questions, and drawing conclusions (Hamdiyati \& Kusnadi, 2007). This laboratory activity can improve scientific attitudes as well as improve the creativity and hands-on ability of students (Proulx, 2013). But look at the current conditions, where students study online. While these activities are commonly done in the school laboratory. This causes difficulty for teachers when interacting indirectly with learners because it is limited only to online activities in carrying out practice trial activities. In addition, because the laboratory tools used in practice activities are difficult to find around the house. Conditions like this will be a barrier because the attitude and expectations of teachers are not by their expectations to teach science (Adisendjaja, 2008). One alternative that can be done is to do a practice based on local materials. This procedure can be used as an option in practice activities. By using local materials tools and materials can be found in everyday life so that it is easier to do. This study aims to analyze the profile and ability of biology teachers in high school in designing and conducting local material-based bacterial/fungal cultivating practice trials during the Covid-19 pandemic. This is because, since the learning system at home, students difficulty can not carry out laboratory activities in school and carry out practice at home because of the limited practice tools. So from this research, it is expected that teachers can innovate on a practice activity using materials that are easily found in the surrounding environment.

\section{Research Method}

This research uses qualitative descriptive research methods. Qualitative descriptive methods are studies that describe real phenomena systematically, factually, and accurately regarding the phenomena investigated (Rukajat, 2018). Research provides an overview of the ability of biology teachers in designing and carrying out local material-based practice trials. This research was conducted at senior high school 1 West Bandung Regency of West Java Province from June to September 2021. This training activity is carried out with blended training, participants follow a series of activities ranging from webinars, self-practices, and evaluation of the results of activities.

The data source in this study is primary data obtained through observations, interviews, and questionnaires to participants. In addition, secondary data was obtained from books, journals as well as sources relevant to research. The subject in this study was a 
biology teacher of MGMP High School in West Bandung Regency as many as 33 people. The data was collected by looking at teacher profiles, analyzing lesson plan, student worksheet documents as well as practice reports of bacterial/fungal cultivating practices that had been created by teachers. In addition, data on training activities and constraints in practice activities in school. Data analysis is done inductively. Researchers study, analyze, interpret and draw conclusions from phenomena on the ground. Then the data analysis process is carried out by data population, data presentation, and conclusions. Data validity tests include data credibility tests, data reliability tests, external validity/generalizations. Data credibility tests are conducted by: extension of observations, increased persistence, triangulation, and discussion with colleagues (Sodik, 2015; Ahyar et al., 2020). The implementation of this research activity is seen in Figure 1.

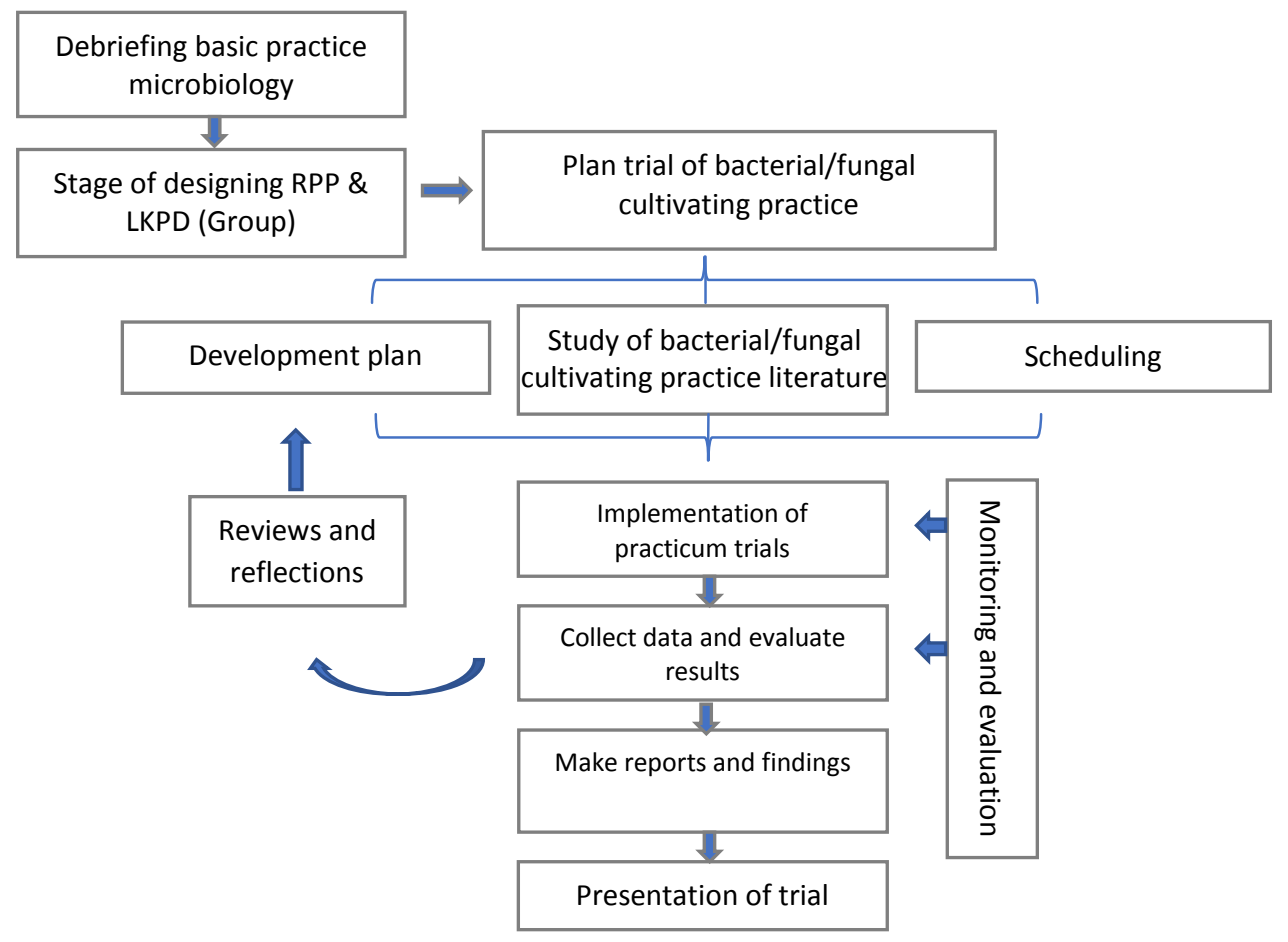

Figure 1. Stages of Bacterial/Fungal Cultivating Practice Trials (Kusnadi et al., 2012)

\section{Results and Discussion}

Research results were based on student worksheet instruments, lesson plan, limited trial results, interviews, questionnaires, and documentation during the study. The following is an exposure of the results and discussion of the research.

\section{Analysis of Senior High School Biology Teacher Profile}

Biology teachers today are faced with many challenges in the learning process. This challenge arises due to the development of digital technology. This can affect learning technology and character changes in students. In addition, the current conditions are difficult to carry out learning activities, especially practices due to limited tools and materials. This can be supported by how the characteristics and profile of biology teachers are qualified both in terms of knowledge and creativity. 
Table 1. Profile of Senior High School Biology Teacher in West Bandung Regency

\begin{tabular}{|c|c|c|c|}
\hline \multicolumn{2}{|c|}{$\begin{array}{l}\text { Characteristics of Classroom } \\
\text { Teachers }\end{array}$} & \multicolumn{2}{|c|}{$\begin{array}{l}\text { Characteristics of the Learning } \\
\text { Experience }\end{array}$} \\
\hline $\begin{array}{l}\text { Classroom } \\
\text { Teacher }\end{array}$ & Sum & Experience & Sum \\
\hline $\mathrm{X}$ & 9 & $<5$ years & 6 \\
\hline XI & 7 & $5-10$ years & 6 \\
\hline XII & 14 & \multirow{2}{*}{$>10$ years } & \multirow{2}{*}{21} \\
\hline X, XI, XII & 3 & & \\
\hline \multicolumn{2}{|c|}{ PPG } & \multicolumn{2}{|c|}{ Follow similar activities } \\
\hline Experience & Sum & Experience & Sum \\
\hline PPG & 21 & Yes & 5 \\
\hline Not yet certified & 12 & Not & 28 \\
\hline
\end{tabular}

The results of the analysis of qualification data and profiles of high school biology teachers in the West Bandung Regency display several characteristics. The results showed that $100 \%$ qualified S1 (Strata one). In addition, the characteristics of teaching levels can be seen in Table 1. Biology teacher class X as many as 9 people, biology teacher class XI as many as 7 people, a biology teacher who teaches class XII as many as 14 people and 3 teachers teach at all three levels in high school. Meanwhile, as many as $63 \%$ of teachers have implemented PPG (Teacher Professional Education). The teacher already has special skills both in terms of competence and professionalism to improve the quality of learning. The results showed that teachers who follow PPG have aspects of curriculum mastery and good learning organizing (Rahmawati, 2018). In addition, when viewed from teaching experience, 63\% of teachers have more than 10 years of teaching experience. This is in line with Prayitno's research, (2019) that the experience of simultaneous teaching has a significant influence on the professional competence of teachers. On the other hand, activities like this are still slightly followed by teachers, only as many as $15 \%$ of teachers have attended the training.

\section{Analysis of Lesson Plan, Student Worksheet, and Report}

Based on the results of the analysis on the achievements of lesson plan, student worksheet (student worksheet) and the results of limited trials that have been made and conducted by teachers obtained data that has been compiled in Figure 2.

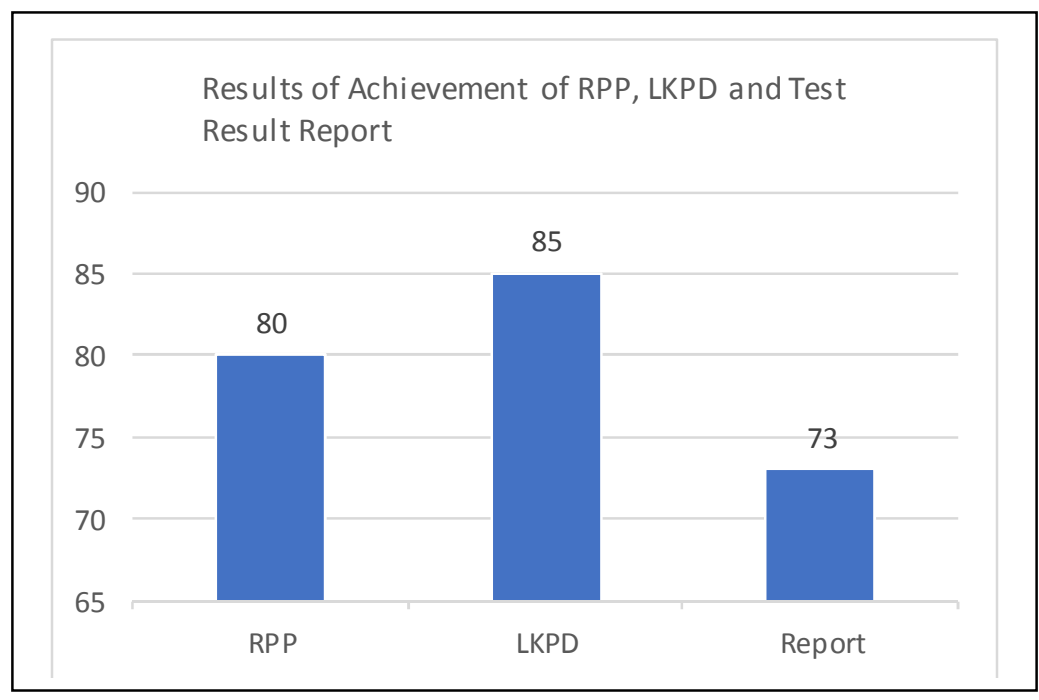

Figure 2. Analysis of Lesson Plan, Student Worksheet, and Test Results Report 
Data on the results of research on the results of lesson plan, student worksheet, and limited test results have been made by biology teachers and analysis. Lesson plan achievement provides information that the Lesson plan review results obtained a value of $80 \%$ (good) from a score of $100 \%$. lesson plan components such as the identity of the subjects, $\mathrm{KI}$ and $\mathrm{KD}$, the selection of learning resources is good enough. But there are some weaknesses such as systematic goals that are incomplete, in the teacher learning scenario is still dominant, assessment of attitudes that are not outlined, and less clear learning scenarios. The use of lesson plan certainly has a very important role. Good learning is initiated by careful and measurable planning through preparation by the competence of learners (Zendrato, 2016). As for the results of the analysis to see the feasibility of using student worksheet used by teachers. Eligibility achievement obtained a value of $85 \%$ (good) from a score of $100 \%$. These criteria include content, presentation, language, radiography, ease of use, suitability of display, and usability of student worksheet features. The worksheet has contained the suitability of KI and KD and is for learning. The presentation of worksheets also has scientific stages, the use of clear and straightforward language rules, the availability of task space, simple sentences and not double-meaning, and instructions that are easy to understand. Appropriate worksheets can help learners in understanding concepts and recognizing the environment around them (Widodo, 2017). Then the results of limited trials were also conducted by these teachers. The results showed that $73 \%$ (sufficient) of $100 \%$ regarding the results of practice trials were attached in the practice report. There are some good things such as writing practice titles, the use of experimental tools and materials using local materials, systematic data processing. But other weaknesses were also found, such as the absence of citations based on theory, still found experimental results and discussions that are not relevant, no conclusions, and the absence of literature studies on the results of the limited trial.

\section{Analysis of training activities and constraints of practicum activities}

In addition to teacher profiles, the results of lesson plan, student worksheet, and report, analyzed training activities. The questionnaire is about the participants' responses to practice designing and trial activities. The results of the questionnaire achievement are found in Figure 3.

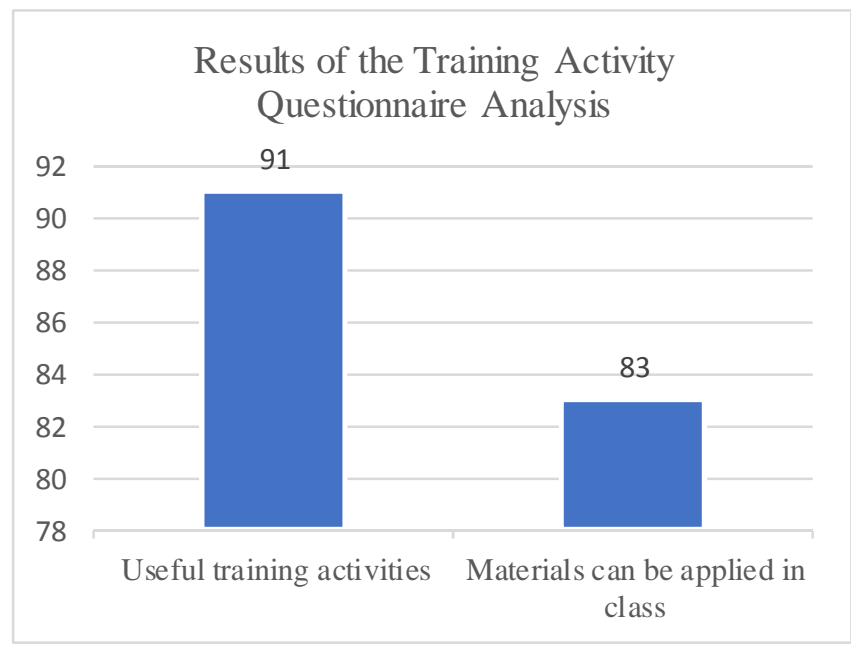

Figure 3. Results of Analysis of Training Activities

Based on the results obtained that $91 \%$ of participants think that the activities of designing and testing practice are very useful, $83 \%$ of participants think that the material that has been 
delivered can be applied in school. This is supported by research conducted by Nau and Missa (2019) that training activities designing learning practices make teachers understand practice activities and innovate practice design. As well as other research from Novallyan (2018) that there is an increase in understanding through the implementation of practice training activities. In addition, an analysis of the questionnaire about the difficulties and constraints of practice in school. Microbiological practices in schools have difficulties and obstacles. Such difficulties such as inadequate tools and materials, difficulties in the preparation of simple practices, abstract materials, and difficulties when the process of making biotechnological products. While there is a positive response related to the continuity of trials practice training activities based on local material. Some participants assume that this activity adds to the learning experience in the teacher to improve the competence of the teacher.

So that through the training activities make the teacher's understanding and experience in designing and conducting an science learning practice experiment. Teacher understanding of IPA practice with simple tools and materials that are easy to find makes it easy for teachers to design simple practice activities. Activities can help to take advantage of existing local sources. One aspect such as the use of presto pans to replace autoclave tools that are difficult to melt in the laboratory. Activities are also considered applicable even in the pandemic era and carried out independently at home using local materials. The motivation and target participants of this activity also received a positive response such as being able to update information and recall material related to bacterial or fungal cultivating. Then add knowledge in learning about mushroom practices making it easier to manage classes. Participants can get strategies to teach the cultivating of bacteria or fungi and improve the quality of learning that can be applied in schools. The expected follow-up of the material in subsequent activities is the development of material-related materials related to the basic competencies of modern biotechnology, applied microbiology, cell biology, or cell metabolism as well as the use of virtual labs that can be applied in schools.

\section{Conclusion}

The conclusion obtained from the results of this study is that the ability profile of west Bandung High School biology teachers can meet the standards in the assessment of biology teachers. Activities in designing and conducting practice trials such as the use of lesson plan, student worksheet, and trialing activities have been carried out. The results showed that the activity of designing and testing cultivating practices was already good. But there are still some shortcomings such as in terms of the preparation of lesson plan, preparation of student worksheet, and report of the final results of practice activities. Practical design and trial activities received a positive response because several problems can be overcome in this activity. One of them is the use of tools and materials that are difficult to obtain can be replaced with tools and materials using local materials.

\section{Recommendation}

Based on the results of research that has been done, it is recommended that teachers as educators can carry out a scientific renewal and competence to facilitate the learning activities of learners in various situations. In addition, the results of this study are expected to make other researchers expand studies on the activities of designing and conducting trials not only adaptive bacterial and fungal cultivating during the Covid-19 pandemic. 


\section{References}

Adisendjaja, Y. H. (2008). Kegiatan Praktikum Dalam Pendidikan Sains. Fpmipa UPI, 1-14. Ahyar, et al (2020). Metode Penelitian Kualitatif \& Kuantitatif. Yogyakarta. CV. Pustaka Ilmu.

Amanda, R. (2018). Profesi Pendidik dan Tenaga Kependidikan (Amiruddin (ed.); Vol. 148). Lembaga Peduli Pengembangan Pendidikan Indonesia (LPPPI).

Hamdiyati, Y., \& Kusnadi. (2007). Profil Keterampilan Proses Sains Mahasiswa Melalui Pembelajaran Berbasis Kerja Ilmiah Pada Matakuliah Mikrobiologi. Jurnal Pengajaran Matematika Dan Ilmu Pengetahuan Alam, 9(2), 36. https://doi.org/10.18269/jpmipa.v9i2.324

Hasanah, A. (2012). Pengembangan Profesi Guru. CV Pustaka Setiia

Husna, R., Roza, Y., \& Maimunah, M. (2021). Identifikasi Kesulitan Guru Matematika Dalam Pelaksanaan Pembelajaran Daring di Masa Pandemi Covid-19. Jurnal Kependidikan: Jurnal Hasil Penelitian dan Kajian Kepustakaan di Bidang Pendidikan, Pengajaran dan Pembelajaran, 7(2), 428-436. doi:https://doi.org/10.33394/jk.v7i2.3333

Kemendikbud. (2018). Peraturan Menteri Pendidikan Dan Kebudayaan Republik Indonesia Nomor 37 Tahun 2018.

Kusnadi, Rochintaniswaty, D., \& Kusumawaty, D. (2005). Mengembangkan Kemampuan Mahasiswa Pendidikan Biologi Dalam Mengisolasi Plasmid Bakteri Sebagai Pengayaan Praktikum Mikrobiologi. Jurnal Pengajaran MIPA, 6(2), 27-37.

Kusnadi, Rustaman, N. Y., Redjeki, S., \& Aryantha, I. N. P. (2012). Analisis Kemunculan Keterampilan Spesifik Lab Mikrobiologi Melalui Pembelajaran Mikrobiologi Berbasis Proyek Inkuiri "Mini-Riset" Mahasiswa Biologi. Jurnal Pengajaran Matematika Dan Ilmu Pengetahuan Alam, 17(1), 53. https://doi.org/10.18269/jpmipa.v17i1.236

Lestiyani, P. (2020). Analisis Persepsi Civitas Akademika Terhadap Konsep Merdeka Belajar Menyongsong Era Industri 5.0. Jurnal Kependidikan: Jurnal Hasil Penelitian dan Kajian Kepustakaan di Bidang Pendidikan, Pengajaran dan Pembelajaran, 6(3), 365372. doi:https://doi.org/10.33394/jk.v6i3.2913

Millar, R. (2002) Thinking about practical work. In Aspects of teaching secondary science: perspectives on practice, ed. Amos, S. and Boohan, R. Ch. 6. London:RoutledgeFalmer

Millar, R. (2004). The role of practical work in the teaching and learning of science. Washington DC: National Academy of Science

Nau, G. W., \& Missa, H. (2019). Pelatihan Praktikum Sederhana Bagi Guru-Guru Ipa Smp Di Kecamatan Mollo Utara Kabupaten Timor Tengah Selatan. Jurnal Pengabdian Kepada Masyarakat, 24(4), 905. https://doi.org/10.24114/jpkm.v24i4.12781

Novallyan, D., Utami, W., Susanti, T., \& Nehru, N. (2019). Evaluation of the Effectiveness of Practical Inquiry-based Biology Course. 3rd Asian Education Symposium (AES 2018), 253(Aes 2018), 253-255. https://doi.org/10.2991/aes-18.2019.19

Prayitno, R. (2019). Pengaruh Tingkat Pendidikan Dan Pengalaman Mengajar Terhadap Kompetensi Profesional Guru Pada Mata Pelajaran Ips Di Sd Sekecamatan Buntu Batu Kabupaten Enrekang. Pendidikan IPS, 148(2), 148-162.

Proulx, M. J. (2013). Introducing the Process and Content of Research into Lectures, the Laboratory, and Study Time. College Teaching, 61(3), 85-87. https://doi.org/10.1080/87567555.2012.720311 
Rahmawati, M. C. (2018). Pengaruh Pendidikan Profesi Guru ( PPG ) Terhadap Pengetahuan Konten Pedagogik (Pedagogical Content Knowledge) Guru Peserta PPG Prajabatan Dalam Pembelajaran IPS. keguru: Jurnal Ilmu Pendidikan Dasar, 9916, 26-37.

Rhavy Ferdyan, Lufri, Z. (2020). Content Analysis and Implementation of Biology Online Learning Materials in SMA/MA/SMK During The COVID-19 Pandemic. Journal of Biology Education, 9(3), 341-348. https://doi.org/10.15294/jbe.v9i3.42637

Rustaman, N.Y. (2005). Peranan Praktikum Dalam Pembelajaran Biologi. (Makalah). Disampaikan pada pelatihan bagi teknisi dan laboran perguruan tinggi Kerjasama FPMIPA IKIP Bandung dengan direktorat Jenderal pendidikan Tinggi. Bandung : FPMIPA IKIP

SCORE (2009) Getting practical: a framework for practical science in schools. London: DCSF. Available at: www.scoreeducation.org/downloads/practical_work/framework.pdf

Sodik, S. S. (2015). Dasar Metodologi Penelitian. Yogyakarta. Literasi Media Publishing. Supriatno, B. (2018). Praktikum untuk Membangun Kompetensi. Proceeding Biology Education Conference, 15(1), 1-18.

Suriansyah, A., Ahmad, A., \& Sulistiyana. (2015). Profesi Kependidikan "Perspektif Guru Profesional" (1st ed., Vol. 148). RajaGrafindo Persada.

Undang-Undang Republik Indonesia Nomor 14 Tahun 2005 tentang Guru an Dosen. Jakarta: Departemen Pendidikan Nasional

Widodo, S. (2017). Pengembangan Lembar Kegiatan Peserta Didik (STUDENT WORKSHEET) Berbasis Pendekatan Saintifik untuk Meningkatkan Keterampilan Penyelesaian Masalah Lingkungan Sekitar Peserta Didik di Sekolah Dasar. JPIS Jurnal Pendidikan Ilmu Sosial, 26(2), 189-204. http://ejournal.upi.edu/index.php/jpis

Woodley, E. (2009). Practical work in school science - why is it important? Physics Bulletin, 16(7), 280-280. https://doi.org/10.1088/0031-9112/16/7/006

Zendrato, J. (2016). Tingkat Penerapan dalam Pelaksanaan Pembelajaran di Kelas Suatu Studi Kasus di SMA Dian Harapan Jakarta Juniriang Zendrato FIP - Universitas Pelita Harapan ABSTRAK. Scholaria: Jurnal Elektronic Universitas Kristen Satya Wacana, 6, 58-73. 